\title{
Temporal variation in the composition of ant assemblages (Hymenoptera, Formicidae) on trees in the Pantanal floodplain, Mato Grosso do Sul, Brazil
}

\author{
Stela de Almeida Soares ${ }^{1,4, *}$, Yzel Rondon Suarez 2,7, Wedson Desidério Fernandes ${ }^{1,6}$, Patrícia Mara Soares \\ Tenório ${ }^{2,8}$, Jacques Hubert Charles Delabie ${ }^{3,9}$ \& William Fernando Antonialli-Junior ${ }^{1,2,5}$
}

\begin{abstract}
'Programa de Pós-graduação em Entomologia e Conservação da Biodiversidade, Universidade Federal da Grande Dourados (UFGD). Rodovia Dourados/Itahum, Km 12, Caixa Postal 241, 79.804-970, Dourados-MS, Brasil. Email: wedson@ufgd.edu.br ${ }^{6}$, stelasoares@ufpr.br ${ }^{4}$

${ }^{2}$ Laboratório de Ecologia, Centro Integrado de Análise e Monitoramento Ambiental, Universidade Estadual de Mato Grosso do Sul (CInAM-UEMS, MS). Rodovia Dourados/Itahum, Km 12, Caixa Postal 351, 79.804-907, Dourados-MS, Brasil. Email: williamantonialli@yahoo.com.br ${ }^{5}$, yzel@uems.br ${ }^{7}$,patriciamara@hotmail.com ${ }^{8}$

${ }^{3}$ Laboratório de Mirmecologia, Convênio UESC-CEPLAC, Centro de Pesquisas do Cacau, Caixa Postal 7. CEP 45600-000 Itabuna-BA, Brasil. Email: jacques.delabie@gmail.com ${ }^{9}$

*Corresponding author
\end{abstract}

\begin{abstract}
Temporal variation in the composition of ant assemblages (Hymenoptera, Formicidae) on trees in the Pantanal floodplain, Mato Grosso do Sul, Brazil. In this paper we investigate how seasonal flooding influences the composition of assemblages of ants foraging on trees in the Pantanal of Mato Grosso do Sul. During the flood in the Pantanal, a large area is covered by floods that are the main forces that regulate the pattern of diversity in these areas. However, the effects of such natural disturbances in the ant communities are poorly known. In this sense, the objective of this study was to evaluate the effect of temporal variation in assemblages of ants foraging on trees in the Pantanal of Miranda. Samples were collected during a year in two adjacent areas, one who suffered flooding during the wet period and another that did not suffer flooding throughout the year. In 10 sites for each evaluated habitat, five pitfall traps were installed at random in trees $25 \mathrm{~m}$ apart from each other. In the habitat with flooding, the highest richness was observed during the flooding period, while there was no significant change in richness in the area that does not suffer flooding. The diversity of species between the two evaluated habitats varied significantly during the two seasons. Most ants sampled belong to species that forage and nest in soil. This suggests that during the flood in flooded habitats, ants that did not migrate to higher areas without flooding adopt the strategy to search for resources in the tree canopy.
\end{abstract}

KEYWORDS. Ants; flood and non-flood season; Insecta; richness; species composition.

One of the main challenges in the study of insect communities is to explain what determines species diversity and how it occurs. Many ecological factors have been reported to affect the richness and composition of species in biological communities and different ecological and environmental factors can structure ant communities on different spatial scales (Kaspari \& Weiser 1999; Kneitel \& Chase 2004).

In the wetlands of the Pantanal, Mato Grosso do Sul, Brazil, dry and rainy seasons alternate annually. During the rainy season, a large plain, which includes parts of Paraguay, Bolivia, and Brazil, is covered by the flood (Feener et al. 2008). Floods are the main regulating force of diversity patterns and processes in the area (Adis et al. 2001). Faunal diversity depends on the seasonality of important structural events, which usually leads to the inundation of large areas (Raizer \& Amaral 2001). The Pantanal is one of the least known biomes of Brazil, and it has been suggested that the functional role of invertebrates in this ecosystem has a large contribution to its preservation (Lewinsohn et al. 2005).

The ant family Formicidae is one of the most successful insect groups, and includes one of the highest species number and biomass among invertebrates, being also omnipresent in a wide range of environments (Santos et al. 2003;
Battirola et al. 2005), easy to collect and identify, and responding relatively quickly to habitat changes (Ribas \& Shoereder 2007). In addition, a significant correlation between habitat structural characteristics and structural patterns of ant communities has often been found (Samways 1983; Soares et al. 2007).

Although some previous studies have demonstrated that the coexistence of arboreal ant species is affected by various abiotic and biotic factors (Albrecht \& Gotelli 2001; Blüthgen et al. 2004; Yamane et al. 2010), the effects of natural disturbance on ants have rarely been examined (York 1994; Ratchford et al. 2005; Rodrigo \& Retana 2006). Tropical litter-nesting ants are exposed to a broad array of environmental disturbances, such as treefalls (Feener \& Schupp 1998), army ant predation (Franks \& Bossert 1984; Kaspari \& O’Donnell 2003), and flooding (Majer \& Delabie 1994; Vasconcelos et al. 2000). It is obvious that the flooding regulates the ants' community wetlands of the Pantanal, and studies about the effects of floods on the ant fauna in the Pantanal are important to understand the ecology of communities' regulation (see Adis et al. 2001; Vieira et al. 2010).

Nevertheless, several ants, as other invertebrates, have developed particular survival strategies such as vertical mi- 
gration, in order to assure their survival in periodically flooded ecosystems (Adis et al. 1984). In the Amazon Region, the leafcutting ant Acromyrmex lundi carli Gonçalves, 1961 lives in flood-prone forest areas (várzeas) that remain under water for six months, building underground nests during the dry season, and moving them to treetops and inside tree trunks during the rainy season (Adis 1982). Crematogaster cerasi (Fitch, 1855) also moves its nests inside tree trunks to survive floods (Hölldobler \& Wilson 1990).

Disturbance during periodic flooding could also play a role in structuring ants' communities (Kaspari et al. 2003), such as the ants species can exploit a niche where the density of other ants is insignificant (Nielsen et al. 2010). Adaptations to flooding may be similar to those shown by ants in response to disturbance in general, such as frequent nest relocalization and opportunistic foraging (King et al. 1998; Nielsen et al. 2010; Mertl et al. 2009, 2010).

Mechanisms that determine diversity in Pantanal environments have been only partly investigated (Suárez et al. 2004; Corrêa et al. 2006; Feener et al. 2008; Vieira et al. 2008). Moreover, there is a lack of studies in these environments, which concentrates most of endemic biodiversity, using taxa-models, such as ants. Therefore, to understand how ant populations foraging on trees are affected by the recurrent seasonal floods in the Pantanal floodplains, this study aimed to determine the effect of spatial (flooded vs nonflooded) and temporal variations on the tree ant assemblages (diversity and composition) in the Pantanal of Miranda, state of Mato Grosso do Sul, Brazil.

\section{MATERIAL AND METHODS}

The study sites are located in Pantanal areas in the municipality of Miranda, state of Mato Grosso do Sul, Brazil (20¹0’30.4"S 56³0’22.8"W) (Fig. 1). The river level was obtained from the historical data available at the hydrological data station of the National Water Agency (Agência
Nacional das Águas, ANA), located in the Miranda River (20¹4'27"S 56 $\left.23^{\prime} 46^{\prime \prime} \mathrm{W}\right)$, approximately $25 \mathrm{~km}$ from the experimental area. The lowest, mean, and highest monthly river levels since 1965 were used to calculate the monthly means. April and January were considered the rainiest months, and June and October, the driest months.

Sampling was carried out during the dry and rainy seasons, in two separate areas, one seasonally flooded and the other not flooded with few phyto-physiognomic differences, totaling four separate collections. The dry season was defined according to Zavatini (1992), the climate in Mato Grosso do Sul being humid subtropical, with the rainy season from November to April and the dry season from May to October (Peel et al. 2007). In each collection, we randomly selected 10 points, which were equally divided among flooded and non-flooded areas and distant at $1000 \mathrm{~m}$ intervals from one another. In each point, five traps were distributed. The traps were placed on plants that had more than $15 \mathrm{~cm}$ in circumference at breast height and a minimum height of $1.3 \mathrm{~m}$. Tree pitfall traps used to collect the ants are shown in Ribas et al. (2003). Data were collected for all 10 points during four collections, each point with five tree pitfall traps, the total sampling effort being 100 traps for each habitat.

Seven days later, we collected the traps and the specimens placed in labelled glass containers with $70 \%$ ethanol. The ants collected were identified according to Bolton (1994, 2003). Vouchers were deposited in the collection of the CEPLAC Myrmecology Laboratory (CPDC), under record number \#5521.

The species collected from the traps were recorded and used to estimate the total richness of species in each of the two areas. The abundance data were obtained from a presenceabsence matrix. This procedure is the most appropriate for interspecific comparisons, because it is not affected by colony size or behaviour in recruiting workers, which could lead to overestimation of species with more efficient recruiting systems or of colonies nearer the traps (Tavares et al. 2001).

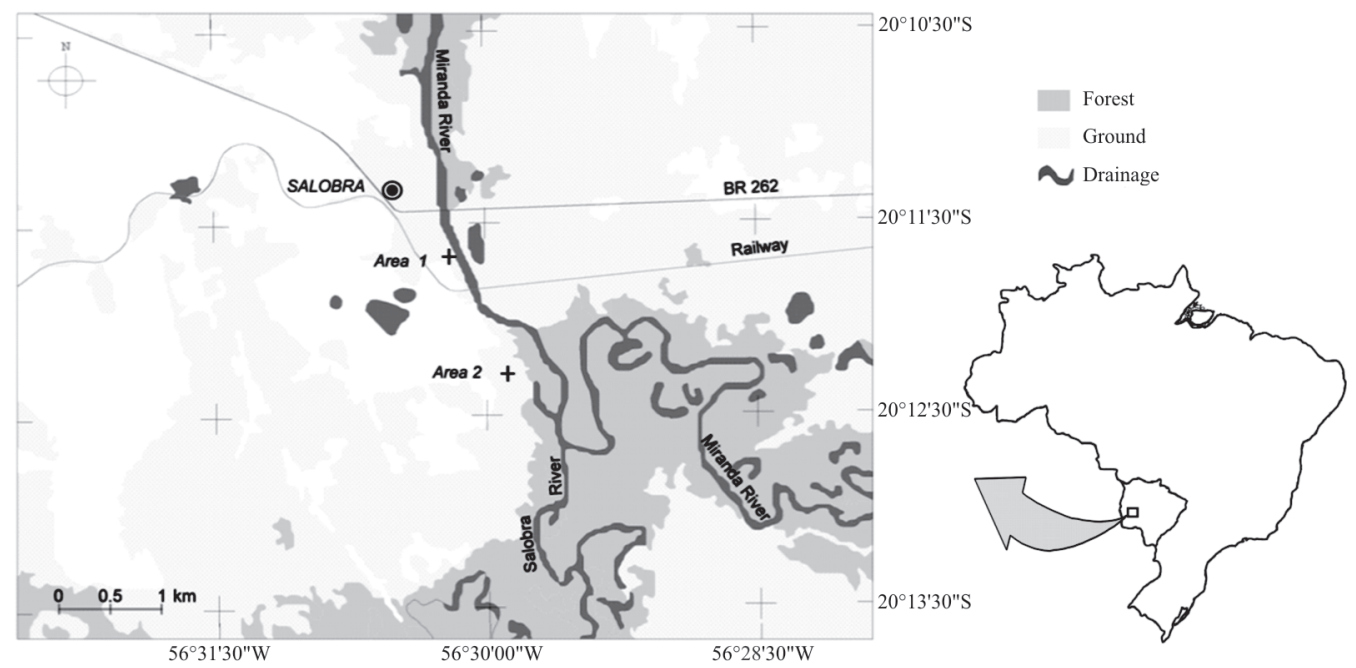

Fig. 1. Location of the two study areas at Miranda, Mato Grosso do Sul, Brazil (area 1: flooded; area 2: non-flooded). 
Species richness was estimated using the Jackknife 1 index with EstimateS 7.5 (Colwell 2001). The Jackknife 1 index is one of the most accurate non-parametric indexes used to express richness in a community (Schmitd et al. 2005) and to obtain the adjusted richness values. The ShannonWiener diversity indexes (Wolda 1983; Mendes et al. 2008) were calculated, as species richness and evenness (Evenness $=\mathrm{H} / \mathrm{Hmax}$ ) to obtain a thorough view of species diversity.

The significance of the difference between richness, evenness and diversity of ant assemblages on trees in each environment and during the dry and rainy seasons was assessed using the analysis of variance (Two-way ANOVA). Richness, evenness and Shannon diversity index were considered the response variables, and the environment, the seasons, and the interaction between environment and season were used as explanatory variables.

An analysis of similarity (ANOSIM), performed with the software R, was used to quantify variation in species composition in each environment and season using the Bray-Curtis similarity coefficient, considered the most efficient for this type of analysis (Lassau \& Hochuli 2004).

The data on species composition to compare sites were submitted to a semi-hybrid multidimensional scaling (MDS) by software R. MDS is an analysis of nonlinear ordination whose results often offer more information on fewer axes than any other indirect ordination technique. The ordination was based on the Bray-Curtis similarity index, comparing the two sites using presence and absence data.

\section{RESULTS}

We collected seventy-five ant morphospecies: 48 in the flood-prone area (30 in the dry season and 36 in the rainy season) and 68 in the non-flood area (50 in the dry season and 42 in the rainy season).

The 75 morphospecies belonged to seven subfamilies, as follows: Myrmicinae (32), Formicinae (12), Ponerinae (8), Ectatomminae (7), Pseudomyrmecinae (6), Dolichoderinae (5), and Ecitoninae (4) (Table I).

Several species, such as Monomorium floricola (Jerdon, 1852), Pheidole sp.1, Solenopsis sp.1, Camponotus crassus (Mayr, 1862), Crematogaster sp.1, and Crematogaster sp. 2 were found in both seasons and in both areas during the study (Table I).

The richness and diversity of ants collected from trees were higher in June and January, during the transition months between the dry and the rainy seasons (Figs. 2, 3 and 4), when the Miranda River is at its lowest level. In April, the richness and diversity of species were greater in the flood areas (Figs. 2 and 3), when the river is at its highest level.

The ANOVA results were significant in interaction between season and environment on the richness $(\mathrm{p}<0.000)$ and species diversity $(\mathrm{p}<0.000)$, although not on equitability $(\mathrm{p}=0.403)$ (Table II).

A significant difference in species composition was observed using the analysis of similarity (ANOSIM) for ant assemblages foraging on trees in both environments $(\mathrm{r}=$ 0.0574 and $p<0.004)$. The same was found for species composition during the dry and the rainy seasons $(r=0.2341$ and $\mathrm{p}<0.001$ ). A multidimensional scaling analysis (Fig. 4) supported these results.
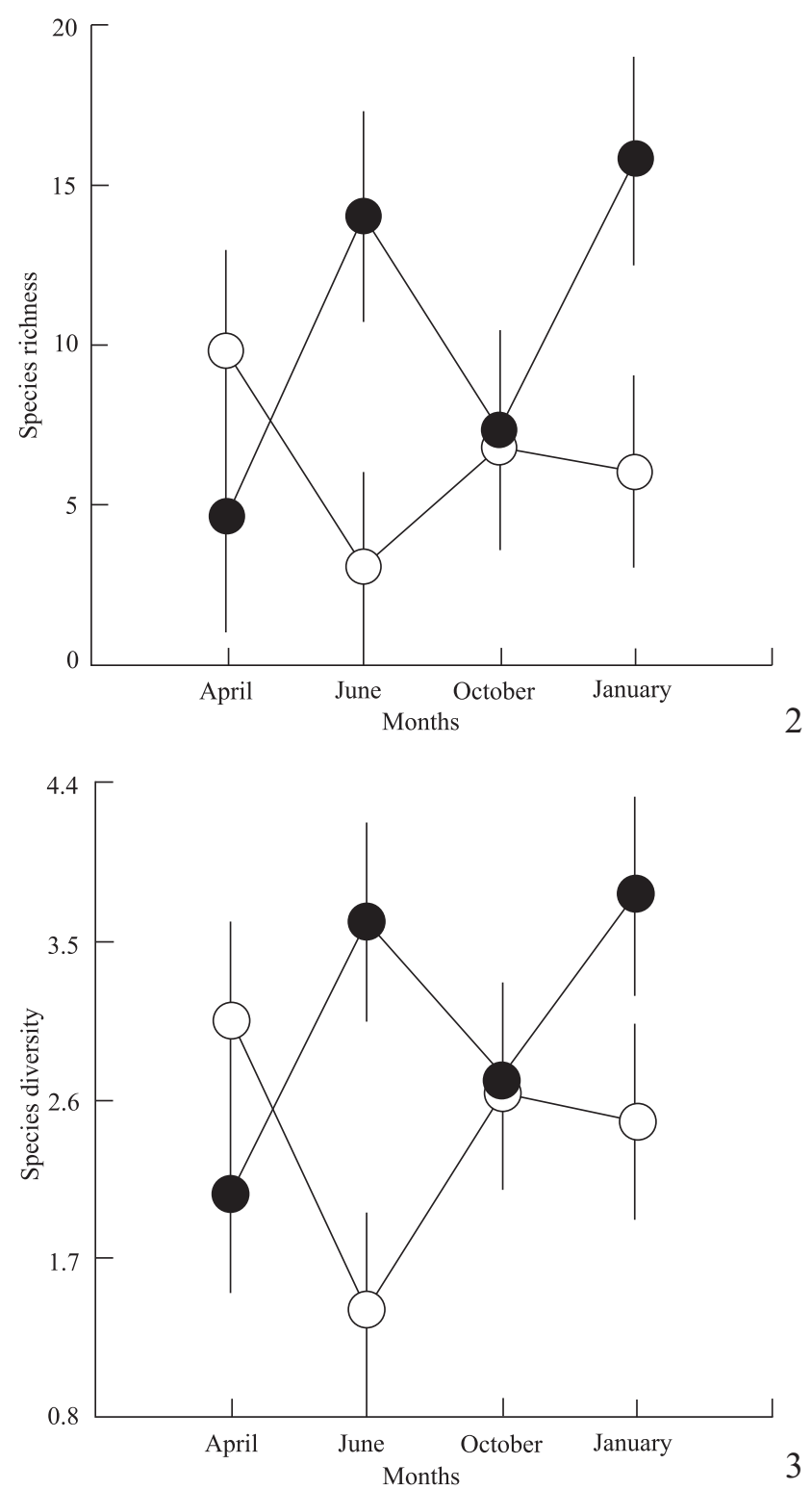

Figs. 2-3. Average values and respective confidence intervals for the number of species (richness) (2) and diversity (3) of ant communities observed on trees in flooded and non-flooded environments in four sampling periods, in a region of the Pantanal in the state of Mato Grosso do Sul, Brazil. * Legend: dry $(\bullet)$ and rainy $(O)$ seasons.

\section{DISCUSSION}

The subfamily Myrmicinae was predominant in both areas (Table I), as is usual in Neotropical ant communities (Corrêa et al. 2006; Ribas \& Shoereder 2007; Feener et al. 2008; Groc et al. 2009). This is a dominant group of ants, 
Table I. Species of ants (Formicidae), and respective number of individuals, that forage on trees situated in flooded and non-flooded areas in a region of the Pantanal in the state of Mato Grosso do Sul, Brazil.

\begin{tabular}{|c|c|c|c|c|c|c|c|c|c|c|c|c|c|c|c|c|c|c|c|}
\hline \multirow[b]{3}{*}{ Myrmicinae } & \multicolumn{4}{|c|}{ Flooded } & \multicolumn{4}{|c|}{ Non-Flooded } & \multirow{2}{*}{ Total } & & \multicolumn{4}{|c|}{ Flooded } & \multicolumn{4}{|c|}{ Non-Flooded } & \multirow{2}{*}{ Tota } \\
\hline & \multicolumn{2}{|c|}{ Dry } & \multicolumn{2}{|c|}{ Rainy } & \multicolumn{2}{|c|}{ Dry } & \multicolumn{2}{|c|}{ Rainy } & & & \multicolumn{2}{|c|}{ Dry } & \multicolumn{2}{|c|}{ Rainy } & \multicolumn{2}{|c|}{ Dry } & \multicolumn{2}{|c|}{ Rainy } & \\
\hline & & & & & & & & & & Camponotus renggeri Emery, 1894 & 0 & 1 & 1 & 0 & 0 & 0 & 0 & 0 & 2 \\
\hline Acromyrmex rugosus Fr. Smith, 1858 & 0 & 0 & 0 & 0 & 0 & 0 & 0 & 1 & 1 & Camponotus rufipes Fabricius, 1775 & 0 & 0 & 0 & 1 & 0 & 0 & 0 & 3 & 4 \\
\hline Atta sexdens Linnaeus, 1758 & 0 & 0 & 0 & 0 & 1 & 0 & 0 & 0 & 1 & Camponotus sexgutattus Fabricius, 1793 & 0 & 0 & 1 & 0 & 0 & 0 & 0 & 1 & 2 \\
\hline Cephalotes atratus Linnaeus, 1758 & 0 & 0 & 3 & 0 & 3 & 0 & 0 & 2 & 8 & Camponotus sp. 1 & 0 & 2 & 0 & 1 & 1 & 1 & 0 & 0 & 5 \\
\hline Cephalotes clypeatus Fabricius, 1804 & 0 & 0 & 0 & 0 & 0 & 2 & 0 & 1 & 3 & Nylanderia guatemalensis Forel, 1902 & 0 & 1 & 0 & 0 & 0 & 1 & 0 & 0 & 2 \\
\hline Cephalotes eduarduli Forel, 1921 & 0 & 0 & 0 & 0 & 1 & 0 & 0 & 0 & 1 & Ectatomminae & & & & & & & & & \\
\hline Cephalotes sp.1 & 0 & 1 & 5 & 1 & 1 & 0 & 0 & 0 & 8 & Ectatomma brunneum Fr. Smith, 1858 & 1 & 0 & 1 & 0 & 5 & 0 & 0 & 0 & 7 \\
\hline Cephalotes sp. 2 & 0 & 1 & 1 & 0 & 1 & 3 & 0 & 0 & 6 & Ectatomma edentatum Roger, 1863 & 0 & 0 & 1 & 0 & 1 & 0 & 0 & 1 & 3 \\
\hline Crematogaster curvispinosa Mayr, 1862 & 0 & 0 & 0 & 0 & 0 & 1 & 0 & 0 & 1 & Ectatomma permagnum Forel, 1908 & 0 & 0 & 0 & 0 & 4 & 0 & 0 & 1 & 5 \\
\hline Crematogaster erecta Mayr, 1866 & 0 & 0 & 0 & 0 & 0 & 2 & 0 & 0 & 2 & Ectatomma planidens Borgmeier, 1939 & 0 & 0 & 0 & 0 & 2 & 0 & 0 & 0 & 2 \\
\hline Crematogaster victima Mayr, 1887 & 0 & 0 & 0 & 0 & 0 & 1 & 0 & 0 & 1 & Ectatomma suzanae Almeida, 1986 & 0 & 0 & 0 & 0 & 1 & 0 & 0 & 0 & 1 \\
\hline Crematogaster sp. 1 & 1 & 2 & 3 & 0 & 2 & 7 & 0 & 1 & 16 & Ectatomma tuberculatum Olivier, 1791 & 0 & 0 & 1 & 0 & 2 & 0 & 0 & 1 & 4 \\
\hline Crematogaster sp. 2 & 0 & 2 & 0 & 1 & 2 & 6 & 0 & 2 & 13 & Ectatomma sp. 1 & 0 & 0 & 2 & 0 & 0 & 0 & 0 & 0 & 2 \\
\hline Monomorium floricola Jerdon, 1852 & 2 & 5 & 11 & 0 & 1 & 2 & 8 & 7 & 36 & Ponerinae & & & & & & & & & \\
\hline Pheidole fallax Mavr, 1870 & 0 & 0 & 0 & 0 & 2 & 0 & 1 & 0 & 3 & Anochetus sp. 1 & 0 & 0 & 0 & 0 & 1 & 0 & 0 & 1 & 2 \\
\hline Pheidole fimbriata Roger, 1863 & 0 & 1 & 0 & 0 & 0 & 0 & 0 & 0 & 1 & Hypoponera sp. 1 & 0 & 0 & 0 & 0 & 0 & 0 & 0 & 1 & 1 \\
\hline Pheidole gertrudae Forel, 1886 & 0 & 0 & 0 & 0 & 0 & 2 & 0 & 0 & 2 & Pachycondyla verenae Forel, 1922 & 0 & 0 & 1 & 0 & 0 & 1 & 0 & 0 & 2 \\
\hline Pheidole radoszkowskii Mayr, 1884 & 0 & 0 & 0 & 0 & 2 & 0 & 0 & 0 & 2 & Pachycondyla marginata Roger, 1861 & 0 & 0 & 2 & 0 & 0 & 0 & 0 & 1 & 3 \\
\hline Pheidole oxyops Forel, 1908 & 0 & 1 & 0 & 1 & 1 & 0 & 0 & 1 & 4 & Pachycondyla villosa Fabricius, 1804 & 0 & 0 & 0 & 0 & 0 & 0 & 1 & 1 & 2 \\
\hline Pheidole sp. 1 & 3 & 5 & 4 & 1 & 7 & 0 & 2 & 0 & 29 & Pachycondyla harpax Fabricius, 1804 & 0 & 0 & 0 & 0 & 0 & 0 & 0 & 1 & 1 \\
\hline Pheidole sp. 2 & 1 & 0 & 1 & 0 & 4 & 0 & 1 & 1 & 8 & Pachycondyla sp. 1 & 1 & 0 & 5 & 0 & 0 & 1 & 0 & 0 & 7 \\
\hline Pheidole sp. 3 & 0 & 0 & 0 & 0 & 3 & 0 & 0 & 2 & 5 & Odontomachus bauri Emery, 1892 & 0 & 0 & 0 & 0 & 1 & 0 & 0 & 1 & 2 \\
\hline Pheidole sp. 4 & 0 & 0 & 0 & 0 & 2 & 0 & 0 & 0 & 2 & Odontomachus sp. 1 & 0 & 0 & 0 & 0 & 1 & 0 & 0 & 0 & 1 \\
\hline Pheidole sp. 5 & 0 & 1 & 0 & 1 & 1 & 0 & 0 & 0 & 2 & Ecitoninae & & & & & & & & & \\
\hline Pheidole sp. 6 & 0 & 0 & 0 & 0 & 0 & 0 & 0 & 1 & 1 & Eciton burchelli Westwood, 1842 & 0 & 1 & 0 & 0 & 0 & 0 & 0 & 0 & 1 \\
\hline Pyramica sp. 1 & 0 & 0 & 0 & 0 & 0 & 1 & 0 & 0 & 1 & Labidus praedator Fr. Smith, 1858 & 0 & 0 & 0 & 1 & 0 & 0 & 0 & 1 & 2 \\
\hline Carebara sp. 1 & 0 & 0 & 1 & 0 & 0 & 0 & 0 & 0 & 1 & Labidus sp. 1 & 0 & 0 & 1 & 1 & 0 & 0 & 0 & 0 & 2 \\
\hline Rogeria sp. 1 & 0 & 0 & 1 & 0 & 1 & 1 & 0 & 0 & 3 & Labidus sp. 2 & 0 & 1 & 0 & 0 & 0 & 0 & 0 & 2 & 3 \\
\hline Solenopsis saevissima Fr. Smith, 1855 & 0 & 0 & 0 & 1 & 3 & 0 & 0 & 6 & 10 & Dolichoderinae & & & & & & & & & \\
\hline Solenopsis sp. 1 & 0 & 3 & 6 & 1 & 2 & 1 & 5 & 2 & 20 & Azteca sp. 1 & 0 & 1 & 0 & 0 & 1 & 2 & 1 & 2 & 7 \\
\hline Solenopsis sp .2 & 1 & 2 & 1 & 0 & 0 & 0 & 0 & 3 & 7 & Dorymyrmex sp. 2 & 2 & 0 & 2 & 0 & 2 & 0 & 3 & 4 & 13 \\
\hline Solenopsis sp. 3 & 0 & 0 & 0 & 0 & 1 & 2 & 0 & 1 & 4 & Dolichoderus bispinosus Olivier, 1792 & 0 & 0 & 3 & 0 & 1 & 0 & 2 & 0 & 6 \\
\hline Wasmannia sp. 1 & 1 & 0 & 0 & 0 & 0 & 0 & 0 & 1 & 2 & Linepithema humile Mavr, 1866 & 0 & 0 & 0 & 0 & 0 & 0 & 0 & 1 & 1 \\
\hline Formicinae & & & & & & & & & & Linepithema angulatum Emery, 1894 & 0 & 0 & 1 & 0 & 0 & 0 & 0 & 0 & 1 \\
\hline Brachymyrmex sp. 1 & 1 & 0 & 3 & 0 & 0 & 0 & 1 & 5 & 10 & Pseudomyrmecinae & & & & & & & & & \\
\hline Camponotus blandus Fr. Smith, 1858 & 0 & 1 & 0 & 0 & 4 & 0 & 0 & 0 & 5 & Pseudomyrmex sp. 1 & 0 & 1 & 0 & 0 & 1 & 1 & 0 & 1 & 4 \\
\hline Camponotus cingulatus Mayr, 1862 & 0 & 1 & 1 & 0 & 0 & 0 & 0 & 1 & 3 & Pseudomyrmex gracilis Fabricius, 1804 & 0 & 1 & 0 & 0 & 3 & 2 & 0 & 4 & 10 \\
\hline Camponotus crassus Mavr, 1862 & 2 & 2 & 1 & 1 & 2 & 2 & 6 & 7 & 23 & Pseudomyrmex schuppi Forel, 1901 & 0 & 0 & 0 & 0 & 0 & 0 & 0 & 1 & 1 \\
\hline Camponotus fastigatus Roger, 1863 & 0 & 0 & 0 & 0 & 1 & 0 & 0 & 0 & 1 & Pseudomyrmex filiformis Fabricius, 1804 & 0 & 0 & 0 & 0 & 1 & 0 & 0 & 0 & 1 \\
\hline Camponotus leydigi Forel, 1886 & 0 & 1 & 0 & 1 & 0 & 3 & 1 & 5 & 11 & Pseudomyrmex kuenckeli Emerv, 1890 & 0 & 0 & 0 & 0 & 0 & 2 & 0 & 0 & 2 \\
\hline \multirow[t]{2}{*}{ Camponotus melanoticus Emery, 1894} & 0 & 0 & 0 & 0 & 0 & 0 & 0 & 2 & 2 & Pseudomyrmex tenuis Fabricius, 1804 & 1 & 2 & 2 & 0 & 2 & 0 & 0 & 3 & 10 \\
\hline & \multicolumn{9}{|c|}{ Continues } & Total & & & & & & & & & 383 \\
\hline
\end{tabular}

which have a wide variety of feeding and nesting habits (Fowler et al. 1991). The genera Pheidole, Solenopsis, and Crematogaster are among those with the highest diversity of species, widest geographical distribution, and highest local abundance (Wilson 2003).

Twenty-five percent of the samples contained species that occurred only once (Table I) and these species may sometimes be classified as "rare" because of inappropriate col- lection methods (Silva \& Silvestre 2004). In our study, the apparent rarity of these species in trees can be explained by the fact that most of them are generalists and forage primarily on the ground. Sometimes these ants also forage on trees, for instance the epigeic species Hypoponera sp., Pyramica sp. and Anochetus sp. (Holldöbler \& Wilson 1990).

The greatest richness of species was observed in the nonflooded area, for each month of data collection. This result 


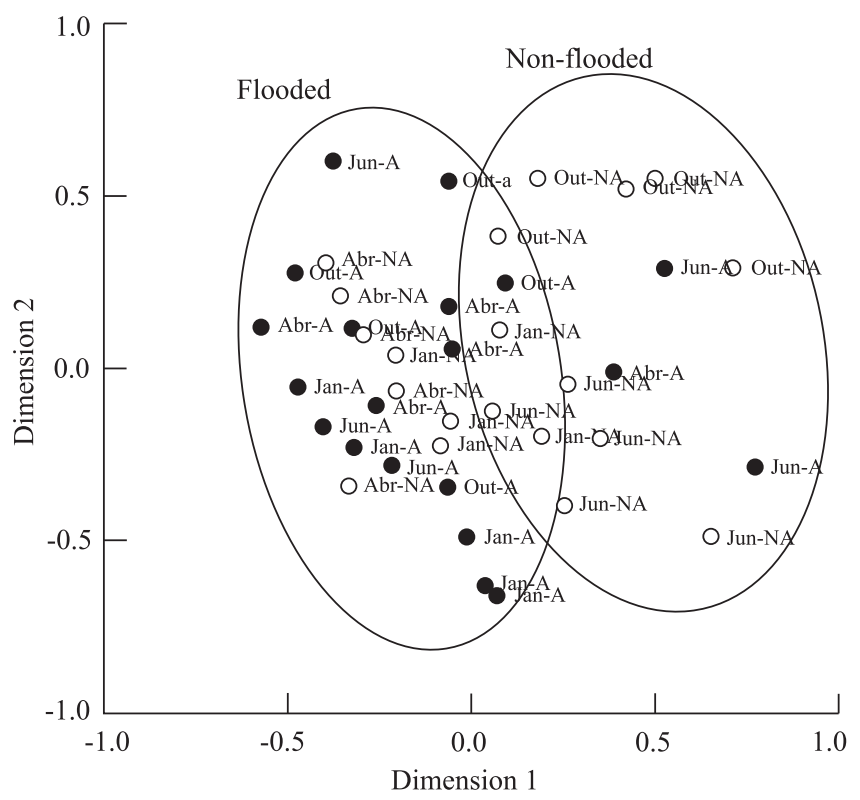

Fig. 4. Ordination by Multidimensional Scaling (MDS) in two dimensions $(\mathrm{R}=0.922)$ of the samples according to the composition of ant species found in trees using the Bray-Curtis similarity index, for the flooded areas (F) and non-flooded (NF) areas, dry and rainy seasons (Apr F; Jun F; Oct F; and Jan F, and Apr NF, Jun NF; Oct FA and Jan NF) respectively, in dry (•) and rainy (O) seasons, Pantanal of the state of Mato Grosso do Sul, Brazil.

Table II. Variance analysis (ANOVA- Two way) for the significance of differences in richness and equitability of ants found on trees in each environment and during the dry and the rainy seasons. The richness and diversity was considered the explanatory variable and the environment, the seasons and the interaction between environment and season, were used as response variables.

\begin{tabular}{clccc}
\hline Variable & \multicolumn{1}{c}{ Source } & $\mathrm{r}^{2}$ & $\mathrm{~F}$ & $\mathrm{p}$ \\
\hline \multirow{3}{*}{ Richness } & 0.78 & 11.37 & $<0.01 \mathrm{~s}$ \\
& Environments & & 2.29 & $0.09 \mathrm{~ns}$ \\
& Season & & 10.67 & $<0.01 \mathrm{~s}$ \\
\hline \multirow{3}{*}{ Evenness } & Environments x Season & 0.41 & 1.11 & $0.30 \mathrm{~ns}$ \\
& Season & & 0.82 & $0.49 \mathrm{~ns}$ \\
& Environments x Season & & 1.00 & $0.40 \mathrm{~ns}$ \\
\hline \multirow{3}{*}{ Diversity } & 0.61 & 1.84 & $<0.01 \mathrm{~s}$ \\
& Environments & & 10.08 & $0.16 \mathrm{~ns}$ \\
& Season & & 11.83 & $<0.01 \mathrm{~s}$ \\
\hline
\end{tabular}

suggests that such areas have more niches available for ground species, which occasionally forage on treetops. Several studies have described the effect of habitat structure on the structure and diversity of ant communities (Samways 1983, Castro et al. 1989, 1990, Ribas et al. 2003, Lange et al. 2008a, 2008b). Other explanations to larger species richness in nonflooded area is the smaller requirements to live in this environment compared to flooded area (eg. adaptations to nests changes and food obtaining), (Calcaterra et al. 2010). Complementarily, the statistical differences in species composition can be explained partially by differences in species richness interacting with occurrence of ant species with dif- ferent biological traits adapted to differences in flood regime (LeBrun et al. 2011).

In October, during the dry season, richness and diversity were equivalent for the two areas (Figs. 2, 3). In January, at the beginning of the rainy season, richness and diversity increased in the non-flooded area and decreased in the floodprone area, suggesting the influence of rainy season in the richness and diversity of ants.

In April, during the rainy season, the situation was the opposite: the richness and diversity of species were greater in the floodplains (Figs. 2, 3). This might occur because during the rainy season the only resources available in floodplains are on treetops, even if we consider the increase in rainfall, which certainly interfere with foraging activities. Nonetheless, rainfall in non-flooded areas can lead to lower foraging activity on tree canopies (Figs. 2, 3), and, consequently, its increase on the ground of areas protected from flooding. Complementarily, evenness did not vary significantly among environments and seasons, suggesting that regardless of the number of ant species sampled the dominance pattern among sampled species does not change, possibly as result of a strong relationship between foraging behaviour of ants and dominance pattern in these communities.

Most of the species observed on trees are normally typically found on the ground. A possible explanation for the larger number of species found foraging on trees during flood periods is their behavioral adaptation during the seasonal inundations. This suggests that during the flood in flooded habitats, ants that did not migrate to higher areas without flooding adopt the strategy to search for resources in the tree canopy. In fact, the organic matter accumulated in tree canopies can be used not only as habitat for many groups of arthropods in the Pantanal, but also as shelter during seasonal inundations (Battirola et al. 2004).

The lowest lands in the Pantanal are periodically flooded, whereas the higher areas usually are not, except during the major pluriannual floods (Vieira et al. 2008). During normal floods, the dry areas serve as "islands" or shelters, for animals that otherwise would not survive the floodings. This has been observed in forest fragments of different regions (Fahrig 2003), more intensively in areas of periodic floods.

As shown by multidimensional scaling (Fig. 4), there is a different group of species in each assemblage and environment, in each season, indicating that the number of species foraging on trees increases during the rainy season. This increase can be explained by the large number of species found on trees that also nest and forage on the ground. Battirola et al. (2004) reported that several species of the poneromorphs, Ecitoninae and Myrmicinae nest mainly on the ground and usually live in association with decomposing plant material such as leaves, branches, or fallen trees.

Our results suggest that, in fact, the flood level significantly affects the dynamics of the composition and diversity of ant species that forage on trees. During the rainy season the richness and diversity of species were greater in the floodplains, probably because during this season the only resources 
available in floodplains are on treetops. On the other hand, evenness did not vary significantly among environments and seasons, suggesting that regardless of the ant species number sampled the dominance pattern among sampled species does not change.

\section{ACKNOWLEDGEMENTS}

The authors are indebted to Foundation the Support to Development of Teaching, Science and Technology in the State of Mato Grosso do Sul (FUNDECT) for granting a scholarship to S. A. Soares (protocol \# 41/100.27.0/2006) and to Bianca Cavíchia Desidério for revising this manuscript. J. Delabie, W. Antonialli-Júnior and Y. R. Súarez acknowledge their grants by the National Council of Scientific and Technological Development (CNPq).

\section{REFERENCES}

Adis, J. 1982. Eco-entomological observations from the Amazon: III. How do leafcutting ants of inundations forests survive flooding? Acta Amazonica 12: 839-840.

Adis, J., Lubin, Y.D. \& Montgomery, G.C. 1984. Arthropods from the canopy of inundated terra firme forests near Manaus, Brazil, with critical considerations on the pyrethrum fogging technique. Studies on Neotropical Fauna and Environment 19: 223-236.

Adis, J., Marques, M.I. \& Wantzen, K.M. 2001. First observations on the survival strategies of terricolous arthropods in the northern Pantanal wetland of Brazil. Andrias 15: 127-128.

Albrecht, M. \& Gotelli, N.J. 2001. Spatial and temporal niche partitioning in grassland ants. Oecologia 126: 134-141.

Battirola, L.D., Marques, M.I., Adis, J. \& Brescovit, A.D. 2004. Aspectos ecológicos da comunidade de Araneae (Arthropoda, Arachnida) em copas da palmeira Attalea phalerata Mart. (Arecaceae) no Pantanal de Poconé, Mato Grosso, Brasil. Revista Brasileira de Entomologia 48: 421-430.

Battirola, L.D., Marques, M.I., Adis J. \& Delabie, J.H.C. 2005. Composição da comunidade de Formicidae (Insecta, Hymenoptera) em copas de Attalea phalerata Mart. (Arecaceae), no Pantanal de Poconé, Mato Grosso, Brasil. Revista Brasileira de Entomologia 49: 107-117.

Blüthgen, N., Stork, N.E. \& Fiedler, K. 2004. Bottom-up control and co occurrence in complex communities: honeydew and nectar determine a rainforest ant mosaic. Oikos 106: 344-358.

Bolton, B. 1994. Identification guide to ant genera of the World. Harvard University Press, Cambridge, MA, xi+222 p.

Bolton, B. 2003. Synopsis and classification of Formicidae. Memoirs of the American Entomological Institute 71: 1-370.

Calcaterra, L.A., Cuezzo, F., Cabrera, S.M. \& Briano, J.A. 2010. Ground ant diversity (Hymenoptera: Formicidae) in the Iberá Nature Reserve, the largest wetland of Argentina. Annals of the Entomological Society of America 103: 71-83

Castro, A.G., Queiroz, M.V.B. \& Araújo, L.M. 1989. Estrutura e diversidade de comunidades de formigas em pomar de citrus. Anais da Sociedade Entomológica do Brasil 18: 229-246.

Castro, A.G., Queiroz, M.V.B. \& Araújo, L.M. 1990. O papel do distúrbio na estrutura de comunidades de formigas (Hymenoptera-Formicidae). Revista Brasileira de Entomologia 34: 201-213.

Colwell, R. 2001. User's guide to EstimateS. Available at http:// viceroy.eeb.uconn.edu/estimates (accessed 05 June 2009).

Corrêa, M.M., Fernandes, W.D. \& Leal, I.R. 2006. Diversidade de formigas epigéicas (Hymenoptera: Formicidae) em capões do Pantanal sul mato-grossense: relações entre riqueza de espécies e complexidade estrutural da área. Neotropical Entomology 35: 724-730.
Fahrig, L. 2003. Effects of habitat fragmentation on biodiversity. Annual Review of Ecology and Systematics 34: 487-515.

Feener, D.H. \& Schupp, E. 1998. Effect of treefall gaps on the patchiness and species richness of Neotropical ant assemblages. Oecologia 116: 191-201.

Feener, D.H., Orr, M.R., Wackford, K.M., Longo, J.M., Benson, W.W. \& Gilbert, L.E. 2008. Geographic variation in resource dominancediscovery in Brazilian ant communities. Ecology 89: 1824-1836.

Fowler, H.G, Forti, L.C., Brandão, C.R.F., Delabie J.H.C. \& Vasconcelos, H. 1991. Ecologia nutricional de formigas, p. 427-433. In: Panizzi, A.R, Parra, J.R.P. (Orgs.). Ecologia Nutricional de Insetos e suas Implicações no Manejo de Pragas. São Paulo, Manole, 359 p.

Franks, N.R. \& Bossert, W.H. 1983. The influence of swarm raiding army ants on the patchiness and diversity of a tropical leaf litter ant community, p. 151-163. In: Sutton, E.L., Whitmore, T.C. \& Chadwick, A.C. (eds.). Tropical Rain Forest: Ecology and Management. Oxford, Blackwell.

Groc, S., Orivel, J., Dejean, A., Martin, J.M., Etienne, M.P., Corbara, B. \& Delabie, J.H.C. 2009. Baseline study of the leaf-litter ant fauna in a French Guianese forest. Insect Conservation and Diversity 2: 183-193.

Hölldobler, B. \& Wilson, E.O. 1990. The Ants. Cambridge, Harvard University Press, $732 \mathrm{p}$.

Kaspari, M. \& Weiser, M. 1999. The size-grain hypothesis and interspecific scaling in ants. Functional Ecology 13: 530-538.

Kaspari, M. \& O’Donnell, S. 2003. High rates of army ant raids in the Neotropics and implications for ant colony and community structure. Evolutionary Ecology Research 5: 933-939.

Kaspari, M,, Yuan, M. \& Alonso, L. 2003. Spatial grain and the causes of regional diversity gradients in ants. American Naturalist 161: 459477.

King, J.R, Andersen, A.N. \& Cutter, A.D. 1998. Ants as bioindicators of habitat disturbance: validation of the functional group model for Australia's humid tropics. Biodiversity and Conservation 7: 16271638.

Kneitel, J.M. \& Chase, J.M. 2004. Trade-offs in community ecology: linking spatial scales and species coexistence. Ecology Letters 7: 69-80.

Lange, D., Fernandes, W.D., Raizer, J. \& Silvestre, R. 2008a. Activity of hypogeic ants (Hymenoptera: Formicidae) in flooded and non-flooded forest patches in the Brazilian Pantanal. Sociobiology 51: 661-672.

Lange, D., Fernandes, W.D., Raizer, J. \& Faccenda, O. 2008b. Predacious activity of ants (Hymenoptera: Formicidae) in conventional and in notill agriculture systems. Brazilian Archives of Biology and Technology 51: 1199-1207.

Lassau, S.A. \& Hochuli, D.F. 2004. Effects of habitat complexity on ant assemblages. Ecography 27: 157-164.

LeBrun, E.G., Moffett, M., Holway, D.A. 2011. Convergent evolution of levee building behavior among distantly related ant species in a floodplain ant assemblage. Insectes Sociaux 58: 263-269.

Lewinsohn, T.M., Freitas, A.V.L. \& Prado, P.I. 2005. Conservation of terrestrial invertebrates and their habitats in Brazil. Conservation Biology 19: 640-645.

Majer, J.D. \& Delabie, J.H.C. 1994. Comparison of the ant communities of annually inundated and terra-firme forests at Trombetas in the Brazilian Amazon. Insectes Sociaux 41: 343-59.

Mendes R.S., Evangelista, L.R., Thomaz, S.M., Agostinho, A.A. \& Gomes, L.C. 2008. A unified index to measure ecological diversity and species rarity. Ecography 31: 450-456.

Mertl, A.L., Wilkie, K.T.R. \& Traniello, J.F.A. 2009. Impact of flooding on the species richness, density and composition of Amazonian litternesting ants. Biotropica 41: 633-641.

Mertl, A.L, Sorenson, D. \& Traniello, J.F.A. 2010. Community-level interactions and functional ecology of major workers in the hyperdiverse ground-foraging Pheidole (Hymenoptera, Formicidae) of Amazonian Ecuador. Insectes Sociaux 57: 441-452.

Nielsen, M.G., Christian, K. \& Source, M.H. 2010. Hypoxic conditions and oxygen supply in nests of the mangrove ant, Camponotus anderseni, during and after inundation. Insectes Sociaux 56: 35-39. 
Peel, M.C., Finlayson, B.L. \& McMahon, T.A. 2007. Updated world map of the Köppen-Geiger climate classification. Hydrology and Earth System Sciences 11: 1633-1644.

Raizer, J. \& Amaral, M.E.C. 2001. Does the structural complexity of aquatic macrophytes explain the diversity of associated spider assemblages? Journal of Arachnology 29: 227-237.

Ratchford, J.S, Wittman, S.E., Jules, E.S., Ellison, A.M., Gotelli, N.J. \& Sanders, N.J. 2005. The effects of fire, local environment and time on ant assemblages in fens and forests. Diversity and Distribution 11: 487-497.

Ribas, C.R, Schoereder, J.H., Pic, M. \& Soares, S.M. 2003. Tree heterogeneity, resource availability, and larger scale processes regulating arboreal ant species richness. Austral Ecology 28: 305-314.

Ribas, C.R. \& Schoereder, J.H. 2007. Ant communities, environmental characteristics and their implications for conservation in the Brazilian Pantanal. Biodiversity and Conservation 16: 1511-1520.

Rodrigo, A. \& Retana, J. 2006. Post-fire recovery of ant communities in Submediterranean Pinus nigra forests. Ecography 29: 231-239.

Samways, M.J. 1983. Community structure of ants (Hymenoptera: Formicidae) in a series of habitats associated with citrus. Journal of Applied Ecology 20: 833-847.

Santos, G.B, Marques, M.I., Adis, J. \& Musis, C.R. 2003. Artrópodos associados à copa de Attalea phalerata Mart. (Arecaceae), na região do Pantanal de Poconé-MT. Revista Brasileira de Entomologia 47: 211-224.

Schmidt, K., Corbetta, R. \& Camargo, A.J. 2005. Formigas (Hymenoptera: Formicidae) da Ilha João da Cunha, SC: composição e diversidade. Biotemas 18: 57-71.

Silva, R.R. \& Silvestre, R. 2004. Riqueza da fauna de formigas (Hymenoptera: Formicidae) que habita as camadas superficiais do solo em Seara, Santa Catarina. Papéis Avulsos de Zoologia 44: 1-11.

Soares, S.A, Lange, D. \& Antonialii-Junior, W.F. 2007. Communities of epigeic ants (Hymenoptera: Formicidae) in an area of reforestation and in native forest. Sociobiology 49: 2-14.

Súarez, Y.R., Petrere-Jr., M.P. \& Catella, A.C. 2004. Factors regulating diversity and abundance of fish communities in Pantanal lagoons, Brazil. Fisheries Management and Ecology 11: 45-50.

Tavares, A.A., Bispo, P.C. \& Zanzini, A.C.S. 2001. Comunidades de formigas epigéicas (Hymenoptera: Formicidae) em áreas de Eucalyptus cloeziana (F. Muell.) e de vegetação nativa numa região de cerrado. Revista Brasileira de Entomologia 45: 251-256.

Vasconcelos, H.L., Vilhena, J.M.S. \& Caliri, C. 2000. Responses of ants to selective logging of a Central Amazonian Forest. Journal of Applied Ecology 37: 508-514.

Vieira, L., Lopes, F.S., Fernandes, W.D. \& Raizer, J. 2008. Comunidade de Carabidae (Coleoptera) em manchas florestais no Pantanal, Mato Grosso do Sul, Brasil. Iheringia, Zoologia, 98: 317-324.

Vieira, A.S., Faccenda, O., Antonialli-Junior, W.F. \& Fernandes, W.D. 2010. Nest structure and occurrence of three species of Azteca (Hymenoptera, Formicidae) in Cecropia pachystachya (Urticaceae) in non-floodable and floodable Pantanal areas. Revista Brasileira de Entomologia 54: $441-445$.

Zavatini, J.A. 1992. Dinâmica climática no Mato Grosso do Sul. Geografia 17: $65-91$.

Wilson, E.O. 2003. Pheidole in the New World: a dominant, hyperdiverse ant genus. Cambridge, Harvard University Press, iii+818 p.

Wolda, H. 1983. Diversity, diversity indices and tropical cockroaches. Oecologia 58: 290-298.

Yamane, H.O., Seiki, T. \& Itioka, T. 2010. Within-tree distribution of nest sites and foraging areas of ants on canopy trees in a tropical rainforest in Borneo. Population Ecology 52: 147-157.

York, A. 1994. The long-term effects of fire on forest ant communities: Management implications for the conservation of biodiversity. Memoirs of the Queensland Museum 36: 231-239. 